\title{
Elucidating the Mechanism by Which Gypsum fibrosum, a Traditional Chinese Medicine, Maintains Cutaneous Water Content
}

\author{
Nobutomo Ikarashi, ${ }^{a}$ Naoki Ogiue,${ }^{a}$ Eri Toyoda, ${ }^{a}$ Marina Nakamura, ${ }^{a}$ Risako Kon, ${ }^{a}$ \\ Yoshiki Kusunoki, ${ }^{a}$ Takashi Aburada, ${ }^{a}$ Makoto Ishii, ${ }^{a}$ Yoshikazu Tanaka, ${ }^{b}$ Yoshiaki Machida, ${ }^{b}$ \\ Wataru Ochiai, ${ }^{a}$ and Kiyoshi Sugiyama*,a \\ ${ }^{a}$ Department of Clinical Pharmacokinetics, Hoshi University; and ${ }^{b}$ Division of Applied Pharmaceutical \\ Education and Research, Hoshi University; 2-4-41 Ebara, Shinagawa-ku, Tokyo 142-8501, Japan. \\ Received June 19, 2013; accepted July 24, 2013; advance publication released online August 2, 2013
}

Aquaporin-3 (AQP3) plays an important role in maintaining the normal water content of the skin. Previously, we revealed that the expression of cutaneous AQP3 increased following oral administration of Gypsum fibrosum (main component: $\mathrm{CaSO}_{4}$ ) to mice. The purpose of this study is to elucidate the mechanism by which Gypsum fibrosum increases the expression of cutaneous AQP3 in a keratinocyte cell line. Gypsum fibrosum or $\mathrm{CaSO}_{4}$ was added to keratinocytes, and the expression level of AQP3, the Ca concentration, the activity of protein kinase $\mathrm{C}$ (PKC), and the degrees of phosphorylation of both extracellular signal-regulated kinase (ERK) and cAMP response element binding protein (CREB) were measured. The mRNA and protein expression levels of AQP3 increased significantly $6 \mathrm{~h}$-post addition of Gypsum fibrosum. In keratinocytes treated with Gypsum fibrosum, increases in the concentration of intracellular Ca, PKC activity, and the phosphorylation of ERK and CREB were observed. Pre-treatment with GF109203X, a PKC inhibitor, suppressed the mRNA expression levels of AQP3. Similarly to treatment with Gypsum fibrosum, the addition of $\mathrm{CaSO}_{4}$ led to the same observations in keratinocytes. It is hypothesized that Gypsum fibrosum causes an increase in the intracellular Ca concentration, PKC activity, and the phosphorylation levels of ERK and CREB, resulting in increased AQP3 expression in keratinocytes. In addition, it is possible that the effect of Gypsum fibrosum is attributable to $\mathrm{CaSO}_{4}$, based on the results demonstrating that the mechanisms of action of Gypsum fibrosum and $\mathrm{CaSO}_{4}$ were nearly identical.

Key words aquaporin-3; calcium; keratinocyte; Gypsum fibrosum

Gypsum fibrosum, of which $\mathrm{CaSO}_{4}$ is a significant component, is found in various Chinese herbal medicines that are used for reducing fevers and alleviating thirst. The antipyretic effect of Gypsum fibrosum was demonstrated in a mouse study that reported treatment with Gypsum fibrosum was able to suppress an increase in body temperature induced by ephedrine. ${ }^{1)}$ There have also been reports that Gypsum fibrosum is capable of alleviating thirst caused by diabetes mellitus in a streptozotocin-induced mouse model of type 1 diabetes mellitus. $\left.{ }^{2}\right)$ However, the detailed mechanisms by which Gypsum fibrosum reduces fever and improves thirst have not been elucidated.

Byakkokaninjinto is a Chinese herbal medicine containing a large amount of Gypsum fibrosum. Byakkokaninjinto is used to relieve thirst and cutaneous pruritus, two symptoms associated with diabetes mellitus. In our previous studies, we have evaluated the ability of Gypsum fibrosum from Byakkokaninjinto to alleviate thirst. The results of these studies demonstrated that oral administration of Byakkokaninjinto to KKAy mice, a model of type 2 diabetes mellitus, ${ }^{3,4)}$ relieved thirst and polyuria caused by diabetes mellitus. ${ }^{5)}$ Additionally, the improvement in these symptoms were attributable to an increase in the expression level of aquaporin-2 (AQP2), a membrane water channel, that is expressed in large quantities in kidneys. ${ }^{5)}$ It has also been shown that an increase in the expression of cutaneous AQP3 is involved in the improvement of cutaneous pruritus that is observed following administration of Byakkokaninjinto. ${ }^{5)}$ In addition, it has been reported that the $\mathrm{CaSO}_{4}$ in Gypsum fibrosum can lead to an increase in

The authors declare no conflict of interest cutaneous AQP3 expression levels by triggering an increase in the concentration of cutaneous $\mathrm{Ca} .{ }^{6)}$

In this study, we elucidated the mechanism by which Gypsum fibrosum leads to an increase in cutaneous AQP3, focusing on the increase in the intracellular concentration of cutaneous $\mathrm{Ca}$. The mechanism by which the expression of cutaneous AQP3 increases following the addition of Gypsum fibrosum was evaluated using the human papillomavirus type 16-immortalized human keratinocyte cell line (PHK16-0b). First, the expression level of AQP3 in keratinocytes was determined following the addition of Gypsum fibrosum. Measurements were performed to determine the intracellular concentration of $\mathrm{Ca}$ and protein kinase $\mathrm{C}$ (PKC) activity, along with an analysis of the degree of phosphorylation of extracellular signal-regulated kinase (ERK) and cAMP response element binding protein (CREB) after cells were treated with Gypsum fibrosum. In addition, the relationship between the increase in AQP3 expression levels and PKC activity was examined using an inhibitor of $\mathrm{PKC}$. Whether $\mathrm{CaSO}_{4}$, a main component of Gypsum fibrosum, was responsible for affecting all of these observed changes was also investigated.

\section{MATERIALS AND METHODS}

Materials The human keratinocyte cell line PHK16-0b (JCRB0141) was purchased from the Japanese Collection of Research Bioresources (JCRB) cell bank (Osaka, Japan), and cells that were passaged 8 to 10 times were used in all of the experiments. Gypsum fibrosum was purchased from Uchidawakanyaku Co., Ltd. (Tokyo, Japan). The $\mathrm{CaSO}_{4} \cdot 2 \mathrm{H}_{2} \mathrm{O}$, MCDB153 medium, bovine serum albumin (BSA), and TRI 
reagent were purchased from Sigma-Aldrich Corp. (St. Louis, MO, U.S.A.). The PKC kinase activity kit was purchased from Enzo Life Sciences Inc. (Farmingdale, NY, U.S.A.). The PKC inhibitor GF109203X was purchased from Calbiochem (La Jolla, CA, U.S.A.). The nuclear extract kit was purchased from Active Motif (Carlsbad, CA, U.S.A.). The goat anti-human AQP3 antibody and donkey anti-goat immunoglobulin G (IgG)-horseradish peroxidase (HRP) antibody were purchased from Santa Cruz Biotechnology Inc. (Santa Cruz, CA, U.S.A.). Rabbit anti-p44/42 mitogen-activated protein kinase (MAPK) (Erk1/2) monoclonal antibody and rabbit anti-phospho-p44/42 MAPK (Erk1/2) (Thr202/Tyr204) monoclonal antibody were purchased from Cell Signaling Technology (Danvers, MA, U.S.A.). The rabbit anti-rat phospho-CREB antibody and the rabbit anti-human CREB antibody were purchased from Upstate Biotechnology, Inc. (Lake Placid, NY, U.S.A.). The donkey anti-rabbit IgG-HRP antibody and the enhanced chemiluminescence system (ECL) plus Western blotting detection reagents were purchased from GE Healthcare (Chalfont, St. Giles, U.K.). The primers were purchased from Invitrogen Corp. (Tokyo, Japan). A high capacity cDNA synthesis kit was purchased from Applied Biosystems (Foster City, CA, U.S.A.), and the iQ SYBR Green Supermix was purchased from BioRad Laboratories (Hercules, CA, U.S.A.). All other reagents were of the highest commercially available grade.

Preparation of Freeze-Dried Extracts of Gypsum $f$ brosum The extract of Gypsum fibrosum was prepared by using a routine method of water decoction as follows: $75 \mathrm{~g}$ of Gypsum fibrosum was immersed in $1 \mathrm{~L}$ of distilled water and boiled for $1 \mathrm{~h}$ until the water volume was reduced to approximately half of the original volume. Then, this solution was cooled to room temperature and filtered through filter paper. The filtrate was then freeze-dried using a freeze-dryer (Eyela freeze dryer FD-1, Tokyo Rikakikai Co., Ltd., Tokyo, Japan). $\mathrm{X}$-Ray diffraction analysis and fluorescent X-ray analysis revealed that the main component of the Gypsum fibrosum extract was $\mathrm{CaSO}_{4}(99.74 \%)$. Trace elements, including $\mathrm{Si}, \mathrm{Na}$, $\mathrm{Sr}, \mathrm{Al}, \mathrm{Cl}, \mathrm{K}, \mathrm{P}, \mathrm{Fe}, \mathrm{Cr}, \mathrm{Ni}$, and $\mathrm{Zn}$, were also detected. ${ }^{6)}$

Cell Culture of Keratinocytes The keratinocytes were maintained in MCDB153 medium $\left(0.03 \mathrm{~mm} \mathrm{CaCl}_{2}\right)$ and supplemented with $5 \mu \mathrm{g} / \mathrm{mL}$ insulin, $0.5 \mu \mathrm{g} / \mathrm{mL}$ hydrocortisone, $10 \mu \mathrm{g} / \mathrm{mL}$ transferrin, $0.1 \mathrm{~mm}$ phosphorylethanolamine, $0.1 \mathrm{~mm}$ ethanolamine, $10 \mathrm{ng} / \mathrm{mL}$ epithelial growth factor, and $40 \mu \mathrm{g} / \mathrm{mL}$ bovine pituitary extract. $\left.{ }^{7,8}\right)$ The cells were plated on a 24 -well plate or a 6 -well plate at a density of $2.5 \times 10^{4}$ cells $/ \mathrm{cm}^{2}$ and incubated in a $\mathrm{CO}_{2}$ incubator. When the cells became subconfluent, Gypsum fibrosum or $\mathrm{CaSO}_{4}$ was added (50 or $100 \mu \mathrm{g} / \mathrm{mL}){ }^{9,10)}$ and the cells were cultured for $0.5,1,6$, or $24 \mathrm{~h}$.

For the experiment in which PKC activity was inhibited, GF109203X (100 nm) was added to subconfluent cells. The cells were first cultured for $30 \mathrm{~min}$ and then treated with Gypsum fibrosum or $\mathrm{CaSO}_{4}$ for $6 \mathrm{~h}$ following treatment with GF109203X.

RNA Preparation from Keratinocytes RNA was extracted from keratinocytes using TRI reagent. The resulting solution was diluted 25-fold with Tris/ethylenediaminetetraacetic acid (EDTA) buffer (TE buffer), and the purity and concentration $(\mu \mathrm{g} / \mathrm{mL})$ of RNA were calculated by measuring the absorbance at 260 and $280 \mathrm{~nm}$ with a U-2800 spectrophotometer (Hitachi High Technologies, Tokyo, Japan).
Real Time Reverse-Transcription Polymerase Chain Reaction (RT-PCR) A high-capacity cDNA synthesis kit was used to synthesize cDNA from $1 \mu \mathrm{g}$ of RNA. The cDNA was diluted 20-fold with TE buffer to prepare a cDNA TE buffer solution. To each well of a 96-well PCR plate, $12.5 \mu \mathrm{L}$ of iQ SYBR Green Supermix, $1.5 \mu \mathrm{L}$ of forward primer $(5 \mathrm{pmol} /$ $\mu \mathrm{L}), 1.5 \mu \mathrm{L}$ of reverse primer $(5 \mathrm{pmol} / \mu \mathrm{L}), 2 \mu \mathrm{L}$ of cDNA TE buffer solution, and $7.5 \mu \mathrm{L}$ of RNase-free water were added. A denaturation temperature of $95^{\circ} \mathrm{C}$ for $15 \mathrm{~s}$, an annealing temperature of $56^{\circ} \mathrm{C}$ for $30 \mathrm{~s}$, and an elongation temperature of $72^{\circ} \mathrm{C}$ for $30 \mathrm{~s}$ were used. The sequences of primers used were as follows: AQP3 forward 5'-agacagccccttcaggattt-3', AQP3 reverse 5'-tccettgccetgaatatctg-3', glyceraldehyde-3-phosphate dehydrogenase (GAPDH) forward 5'-atggggaaggtgaaggtcg-3', and GAPDH reverse 5'-ggggtcattgatggcaacaata-3'. The fluorescence intensity of the amplification process was monitored using the My $\mathrm{iQ}^{\mathrm{TM}}$ single-color real-time RT-PCR detection system (Bio-Rad Laboratories). The mRNA expression levels were normalized to levels of GAPDH mRNA.

Preparation of the Crude Membrane Fraction Keratinocytes were treated with Gypsum fibrosum or $\mathrm{CaSO}_{4}(100 \mu \mathrm{g} /$ $\mathrm{mL}$ ) for $6 \mathrm{~h}$. Control cells were treated with the original medium lacking Gypsum fibrosum or $\mathrm{CaSO}_{4}$. The keratinocytes were harvested with a cell scraper and suspended in lysis buffer $(10 \mathrm{~mm}$ Tris, $150 \mathrm{~mm} \mathrm{NaCl}, 8.5 \mu \mathrm{M}$ leupeptin, $1 \mu \mathrm{M}$ phenylmethylsulfonyl fluoride (PMSF), and $0.5 \%$ NP-40, pH 7.2). The cell suspension was homogenized on ice using an ultrasonic homogenizer, and the homogenate was clarified by centrifugation $\left(15000 \times \boldsymbol{g}\right.$ at $4^{\circ} \mathrm{C}$ for $\left.10 \mathrm{~min}\right)$. The supernatant, which contained the crude membrane fraction, was collected. $^{11)}$

Preparation of the Nuclear Fraction Keratinocytes were treated with Gypsum fibrosum or $\mathrm{CaSO}_{4}(100 \mu \mathrm{g} / \mathrm{mL})$ for $1 \mathrm{~h}$. Control cells were treated with the original medium lacking Gypsum fibrosum or $\mathrm{CaSO}_{4}$. The medium was removed, and the nuclei were extracted using a nuclear extraction kit.

Electrophoresis and Immunoblotting Protein concentrations were measured with the bicinchoninic acid (BCA) method using BSA as a standard. Electrophoresis was performed using Laemmli's method. The protein was diluted 2-fold with loading buffer ( $84 \mathrm{~mm}$ Tris, 20\% glycerol, $0.004 \%$ bromophenol blue, $4.6 \%$ sodium lauryl sulfate, and $10 \%$ 2-mercaptoethanol, $\mathrm{pH}$ 6.8) and loaded onto a polyacrylamide gel. Following gel electrophoresis, the isolated proteins were transferred to a polyvinylidene difluoride (PVDF) membrane. After blocking for $1 \mathrm{~h}$ with a skim milk solution, the membrane was probed for $1 \mathrm{~h}$ at room temperature with a goat antihuman AQP3 antibody (1/500), a rabbit anti-p44/42 MAPK (Erk1/2) monoclonal antibody (1/500), a rabbit anti-phosphop44/42 MAPK (Erk1/2) (Thr202/Tyr204) monoclonal antibody (1/500), a rabbit anti-rat phospho-CREB antibody (1/500), or a rabbit anti-human CREB antibody (1/500). After washing the membrane with TBS-Tween (20 mm Tris- $\mathrm{HCl}, 137 \mathrm{~mm} \mathrm{NaCl}$, and $0.1 \%$ Tween 20, pH 7.6), the membrane was probed for $1 \mathrm{~h}$ at room temperature with an anti-rabbit IgG-HRP antibody $(1: 5000)$ or an anti-goat IgG-HRP antibody (1:5000). After washing the membrane, the ECL plus detection reagent was applied, and proteins were visualized with the LAS-3000 mini (FUJIFILM, Tokyo, Japan) lumino image analyzer.

Determination of the Intracellular Ca Concentration The intracellular $\mathrm{Ca}$ concentration was determined by atomic 
A

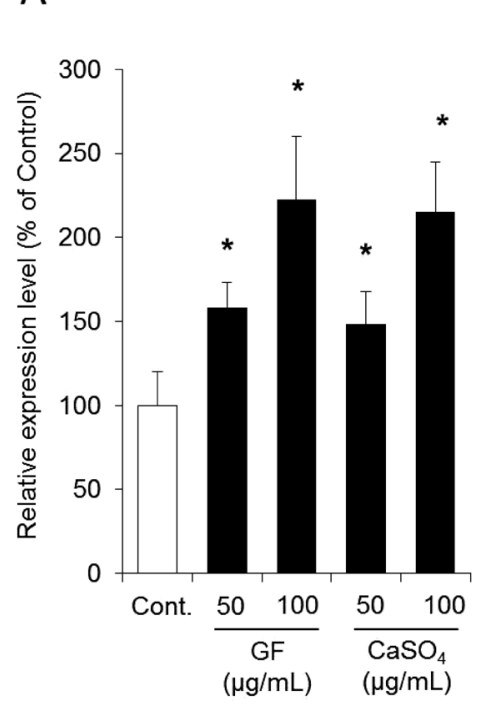

B

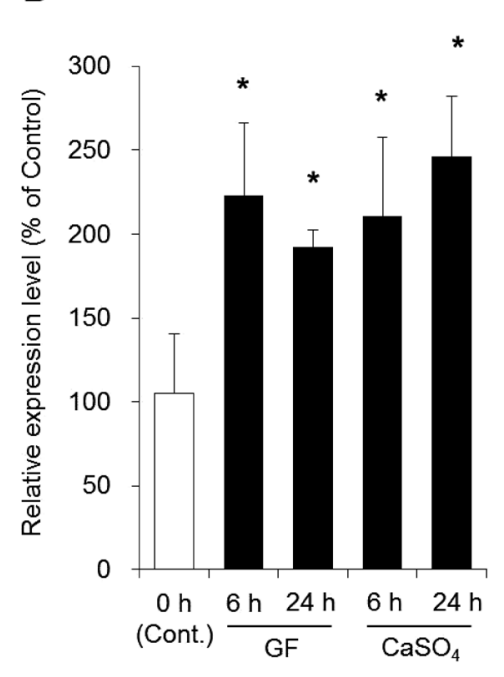

C
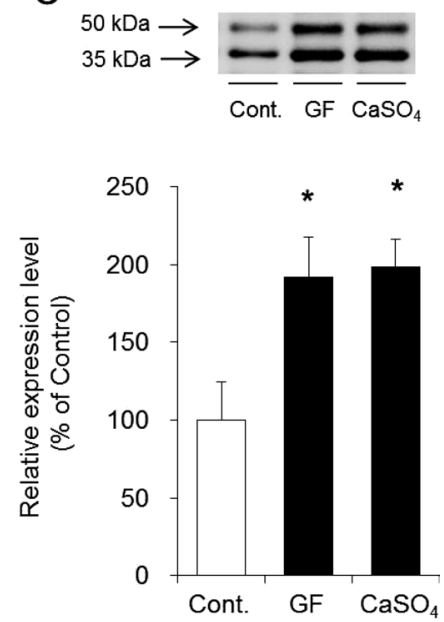

Fig. 1. Effect of Gypsum fibrosum or $\mathrm{CaSO}_{4}$ on AQP3 mRNA and Protein Expression Levels in Keratinocytes

A and B: Keratinocytes were treated with Gypsum fibrosum (GF) or $\mathrm{CaSO}_{4}(50$ or $100 \mu \mathrm{g} / \mathrm{mL}$ ) and harvested $6 \mathrm{~h}$ later (A). Keratinocytes were treated with Gypsum fibrosum or $\mathrm{CaSO}_{4}(100 \mu \mathrm{g} / \mathrm{mL})$ and harvested $0-24 \mathrm{~h}$ later (B). The expression level of AQP3 mRNA was measured by real-time PCR, normalized to the GAPDH level, and then presented with the mean of the control cells set to $100 \%$. The AQP 3 mRNA expression levels of the control cells did not change $24 \mathrm{~h}$ post-treatment with original growth medium. C: Keratinocytes were treated with Gypsum fibrosum or $\mathrm{CaSO}_{4}(100 \mu \mathrm{g} / \mathrm{mL})$ and harvested $6 \mathrm{~h}$ later. The control cells were treated with the original growth medium and handled in a similar manner. The AQP3 protein expression level was measured by Western blot analysis and then presented with the mean of the control cells set at $100 \%$. The data are presented as the mean \pm S.D. of five experiments. Dunnett's test significances; *: $p<0.05 v s$. control.

absorption spectrometry as described below. ${ }^{12)}$ Briefly, the keratinocyte growth media from a 6-well plate was replaced with media containing either Gypsum fibrosum or $\mathrm{CaSO}_{4}$ $(100 \mu \mathrm{g} / \mathrm{mL})$, and these cells were cultured at $37^{\circ} \mathrm{C}$ for $1 \mathrm{~h}$. Control cells were treated with the original medium lacking Gypsum fibrosum or $\mathrm{CaSO}_{4}$. The keratinocytes were initially washed with phosphate buffered saline (PBS) containing $10 \mathrm{~mm}$ EDTA and $150 \mathrm{~mm}$ choline chloride and then again with $150 \mathrm{~mm}$ choline chloride. Cells were lysed with $2 \mathrm{~mL}$ of a solution containing $5 \%$ trichloroacetic acid and $1.75 \% \mathrm{LaCl}_{3}$ and then left to stand for $20 \mathrm{~min}$ at room temperature. The supernatant was recovered by centrifugation $(1000 \times \boldsymbol{g}$ for $10 \mathrm{~min})$, and the $\mathrm{Ca}$ concentration in the supernatant was determined with a standard $\mathrm{Ca}$ solution.

Determination of PKC Activity The growth media used to culture keratinocytes in a 6-well plate was replaced with media containing Gypsum fibrosum or $\mathrm{CaSO}_{4}(100 \mu \mathrm{g} / \mathrm{mL})$, and these cells were cultured at $37^{\circ} \mathrm{C}$ for $1 \mathrm{~h}$. Control cells were treated with the original medium lacking Gypsum fibrosum or $\mathrm{CaSO}_{4}$. After $1 \mathrm{~h}$, the keratinocytes were washed with PBS and then lysed with lysis buffer (20 mM 3-morpholinopropanesulfonic acid, $50 \mathrm{~mm} \beta$-glycerophosphate, $50 \mathrm{~mm}$ sodium fluoride, $1 \mathrm{~mm}$ sodium vanadate, $5 \mathrm{~mm}$ ethylene glycol bis(2aminoethyl ether)- $N, N, N^{\prime}, N^{\prime}$-tetraacetic acid (EGTA), $2 \mathrm{~mm}$ EDTA, $1 \%$ NP-40, $1 \mathrm{~mm}$ dithiothreitol, $1 \mathrm{~mm}$ benzamidine, $1 \mathrm{~mm}$ PMSF, $10 \mu \mathrm{g} / \mathrm{mL}$ leupeptin, and $10 \mu \mathrm{g} / \mathrm{mL}$ aprotinin). The suspension was left on ice for $10 \mathrm{~min}$. The cells were recovered with a cell scraper, sonicated, and the lysate was clarified by centrifugation $\left(13000 \times \boldsymbol{g}\right.$ for $15 \mathrm{~min}$ at $\left.4^{\circ} \mathrm{C}\right)$. The supernatant was recovered, and the PKC activity was assayed with the PKC kinase activity assay kit.

Statistical Analysis Numerical data are expressed as the means \pm standard deviation. Statistical significance was determined using the Dunnett's or Tukey's test for multiple comparisons. The results with $p<0.05$ were considered to be significant.

\section{RESULTS}

Effects of Gypsum fibrosum or $\mathrm{CaSO}_{4}$ on the Expression Levels of AQP3 mRNA and Protein Gypsum fibrosum or $\mathrm{CaSO}_{4}$, either at a concentration of $50 \mu \mathrm{g} / \mathrm{mL}$ or $100 \mu \mathrm{g} / \mathrm{mL}$, was added to keratinocytes, and after $6 \mathrm{~h}$, the AQP3 mRNA expression level was analyzed. The AQP3 mRNA expression level after the addition of Gypsum fibrosum increased in a dose-dependent manner. The changes in the expression of AQP3 due to $\mathrm{CaSO}_{4}$ were similar to the findings observed with Gypsum fibrosum (Fig. 1A).

The mRNA expression level of AQP3 was measured in keratinocytes $24 \mathrm{~h}$ after treatment with either Gypsum fibrosum or $\mathrm{CaSO}_{4}$. The mRNA expression level of AQP3 increased significantly $6 \mathrm{~h}$ after the addition of Gypsum fibrosum when compared with the level of mRNA measured at $0 \mathrm{~h}$ in cells post-treatment. This increase in AQP3 mRNA expression was maintained for up to $24 \mathrm{~h}$ post-treatment with Gypsum fibrosum. The changes in AQP3 expression caused by $\mathrm{CaSO}_{4}$ were nearly identical to those observed with Gypsum fibrosum (Fig. 1B).

The protein expression level of AQP3 was also determined. Two bands of different molecular weight were detected for AQP3. One band was observed at approximately $35 \mathrm{kDa}$ and represented the deglycosylated form of AQP3. The second band was observed at approximately $50 \mathrm{kDa}$ and represented the glycosylated form of AQP3. ${ }^{13,14)}$ Glycosylation has no influence on water permeability. ${ }^{15-17)}$ Therefore, in this study, both of these bands were accounted for when analyzing the total protein expression level of AQP3. ${ }^{18-20)}$ Taking both forms of AQP3 into account, the protein expression level of AQP3 had increased approximately 2-fold the level of the control $6 \mathrm{~h}$ after the addition of Gypsum fibrosum or $\mathrm{CaSO}_{4}$ (Fig. 1C). 
A

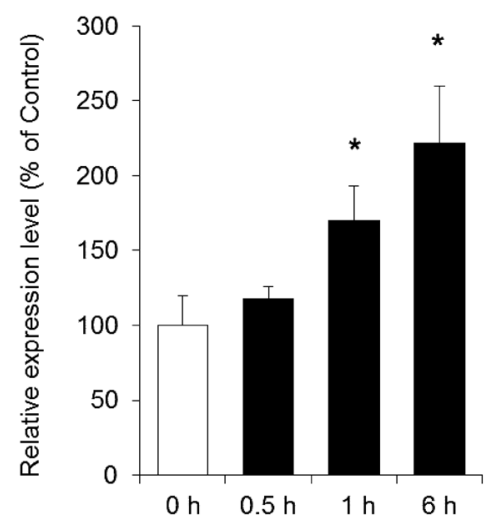

B

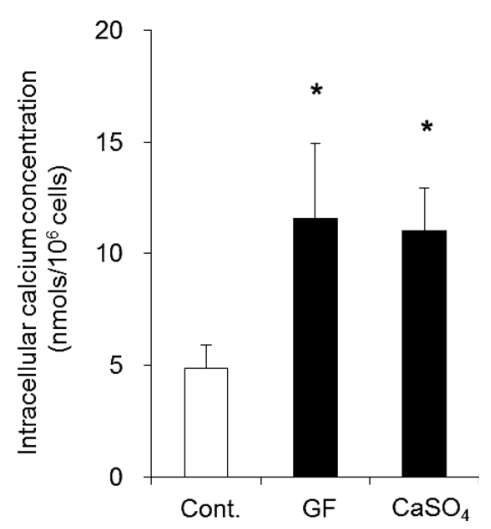

Fig. 2. Effect of Gypsum fibrosum or $\mathrm{CaSO}_{4}$ on the Intracellular Ca Concentration in Keratinocytes

A: Keratinocytes were treated with $\mathrm{CaSO}_{4}(100 \mu \mathrm{g} / \mathrm{mL})$ and harvested $0-6 \mathrm{~h}$ later. The expression level of AQP3 mRNA was measured by real-time PCR, normalized to the GAPDH level, and then presented with the mean of the control cells set to $100 \%$. B: Keratinocytes were treated with $G y p s u m$ fibrosum $(\mathrm{GF})$ or CaSO $(100 \mu \mathrm{g} / \mathrm{mL}$ ) and harvested $1 \mathrm{~h}$ later. The control cells were treated with the original growth medium and handled in a similar manner. The intracellular Ca concentration was determined by atomic absorption spectrometry. The data are presented as the mean \pm S.D. of five experiments. Dunnett's test significances; *: $p<0.05 v s$. control.

Effect of Gypsum fibrosum or $\mathrm{CaSO}_{4}$ on the Intracellular Ca Concentration In our previous study, we demonstrated that the concentration of cutaneous $\mathrm{Ca}$ and the expression level of cutaneous AQP3 were both increased in mice fed a diet containing Gypsum fibrosum. ${ }^{6}$ ) It has been reported that PKC is activated when $\mathrm{Ca}$ enters into cells. ${ }^{21)}$ Additionally, previous studies indicate that the expression level of AQPs increase when PKC is activated. ${ }^{22-24)}$ Therefore, the mechanism of the observed increase in AQP3 expression following the addition of Gypsum fibrosum or $\mathrm{CaSO}_{4}$ was investigated with a focus on the Ca-PKC pathway.

The AQP3 mRNA expression level in keratinocytes did not change at $30 \mathrm{~min}$ after the addition of $\mathrm{CaSO}_{4}$; however, the level started increasing $1 \mathrm{~h}$ after treatment with $\mathrm{CaSO}_{4}$ (Fig. 2A). The intracellular $\mathrm{Ca}$ concentration was measured $1 \mathrm{~h}$ after the addition of Gypsum fibrosum or $\mathrm{CaSO}_{4}$ using atomic absorption spectrophotometry. The results indicated that the addition of Gypsum fibrosum or $\mathrm{CaSO}_{4}$ to keratinocytes significantly increased the intracellular $\mathrm{Ca}$ concentration to a concentration approximately 2 -fold that observed in the control group (Fig. 2B).

Effects of Gypsum fibrosum or $\mathrm{CaSO}_{4}$ on PKC Activation and the Phosphorylation of ERK and CREB It is known that the activation of PKC leads to the phosphorylation of ERK. ${ }^{25-27)}$ Phosphorylated ERK is translocated to the nucleus, ${ }^{28,29)}$ where it phosphorylates CREB. ${ }^{30}$ ) Therefore, the effects of Gypsum fibrosum or $\mathrm{CaSO}_{4}$ on $\mathrm{PKC}$ activation, the phosphorylation of ERK, and the phosphorylation of CREB were examined.

Following the addition of Gypsum fibrosum or $\mathrm{CaSO}_{4}$ to cells, the activity of PKC increased significantly to approximately 4-fold the level observed in the control group (Fig. 3).

By Western blotting, bands for phosphorylated ERK (P-ERK) protein were detected at $42 \mathrm{kDa}$ and $44 \mathrm{kDa}$ (Fig. 4A). Measurements of the protein expression levels indicated that the level of P-ERK $1 \mathrm{~h}$ after the addition of Gypsum fibrosum or $\mathrm{CaSO}_{4}$ increased significantly to approximately 3-fold the level observed in the control group (Fig. 4A).

By Western blotting, a band for phosphorylated CREB (P-CREB) protein was detected at $43 \mathrm{kDa}$ (Fig. 4B). Measure-

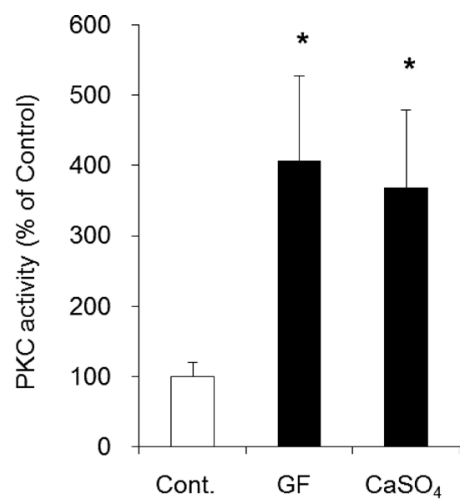

Fig. 3. Effect of Gypsum fibrosum or $\mathrm{CaSO}_{4}$ on the PKC Activity in Keratinocytes

Keratinocytes were treated with Gypsum fibrosum $(\mathrm{GF})$ or $\mathrm{CaSO}_{4}(100 \mu \mathrm{g} / \mathrm{mL})$ and harvested $1 \mathrm{~h}$ later. The control cells were treated with the original growth medium and handled in a similar manner. PKC activity was assayed with a commercial kit and presented with the mean of the control cells set to $100 \%$. The data are presented as the mean \pm S.D. of five experiments. Dunnett's test significances; $*: p<0.05$ vs. control.

ments of protein expression levels indicated that the protein expression level of P-CREB $1 \mathrm{~h}$ after the addition of Gypsum fibrosum or $\mathrm{CaSO}_{4}$ increased significantly to approximately 2-fold the level observed in the control group (Fig. 4B).

Effect of the PKC Inhibitor GF109203X on the Increase in AQP3 Expression Caused by Gypsum fibrosum or $\mathrm{CaSO}_{4}$ GF109203X selectively inhibits the activity of PKC at extremely low concentrations and has thus been widely used for studying signal transduction pathways involving PKC. ${ }^{31,32)}$ Therefore, in this study, GF109203X was used to determine the role that PKC activation may play in the increase in AQP3 expression caused by Gypsum fibrosum or $\mathrm{CaSO}_{4}$.

In cells pre-treated with GF109203X (100 nM), the mRNA expression level of AQP3 did not increase after the addition of Gypsum fibrosum or $\mathrm{CaSO}_{4}$ but remained at a level nearly equal to that of the control cells (Fig. 5).

Based on this observation, it was suggested that the activation of PKC might be involved in the increase in AQP3 expression caused by Gypsum fibrosum or $\mathrm{CaSO}_{4}$. 
A
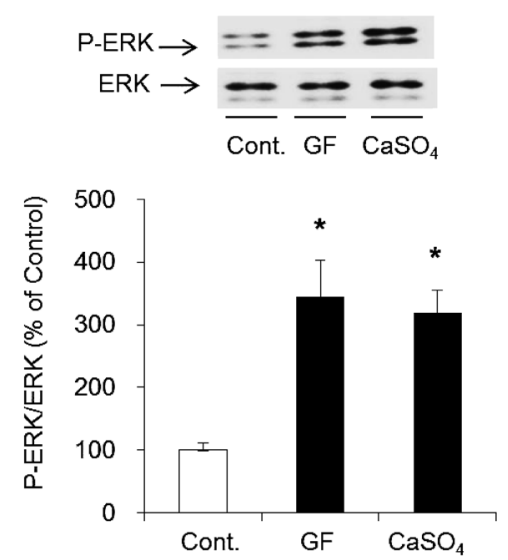

B
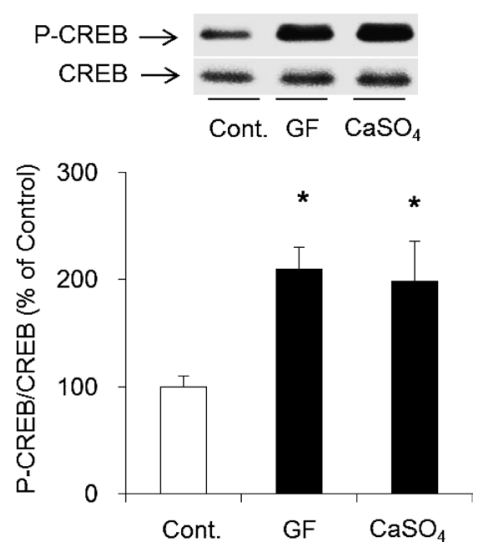

Fig. 4. Effect of Gypsum fibrosum or $\mathrm{CaSO}_{4}$ on the Phosphorylation Levels of ERK and CREB in Nuclear Extracts of Keratinocytes

Keratinocytes were treated with Gypsum fibrosum (GF) or $\mathrm{CaSO}_{4}(100 \mu \mathrm{g} / \mathrm{mL})$ and harvested $1 \mathrm{~h}$ later. The control cells were treated with the original growth medium and handled in a similar manner. Phosphorylated ERK, total ERK, phosphorylated CREB, and total CREB protein expression levels were determined by Western blotting. Phosphorylated ERK (A) and phosphorylated CREB (B) were normalized to the total ERK and total CREB levels, respectively, and then presented with the mean of the control cells set to $100 \%$. The data are presented as the mean \pm S.D. of five experiments. Dunnett's test significances; *: $p<0.05$ vs. control.

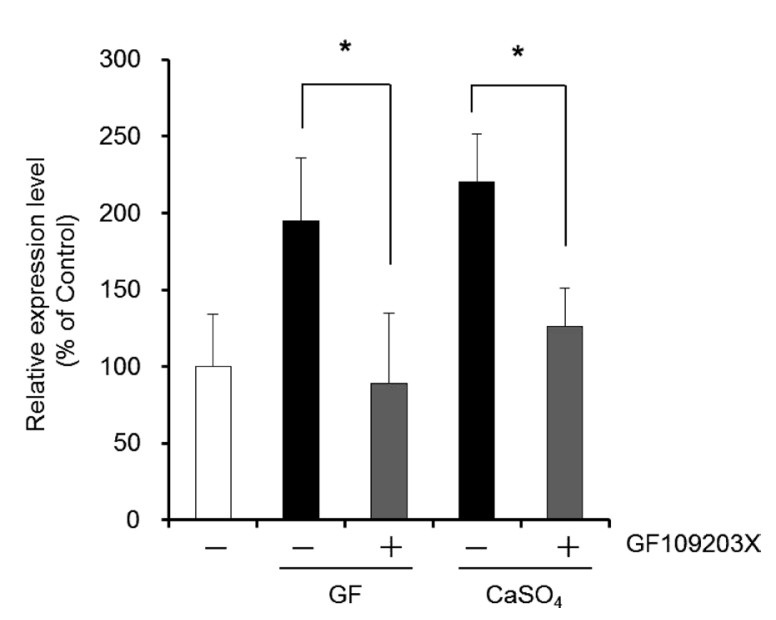

Fig. 5. Effects of Gypsum fibrosum or $\mathrm{CaSO}_{4}$ on the AQP3 mRNA Expression Level in Keratinocytes Pretreated with GF109203X

The keratinocytes were treated with GF109203X (100 nM) for $30 \mathrm{~min}$ and then with Gypsum fibrosum (GF) or $\mathrm{CaSO}_{4}(100 \mu \mathrm{g} / \mathrm{mL})$ for an additional $6 \mathrm{~h}$. The control cells were treated with the original growth medium and handled in a similar manner. The mRNA expression level of AQP3 was determined with real-time PCR, normalized to the GAPDH level, and then presented with the mean of the control cells set to $100 \%$. The data are presented as the mean \pm S.D. of five experiments. Tukey's test: $* p<0.05$.

\section{DISCUSSION}

AQPs are membrane channels that transport water within the human body and are therefore important for the regulation of water homeostasis. ${ }^{33)}$ Each AQP monomer consists of six transmembrane domains. The AQPs function in a tetramer and selectively transport water, glycerol, and other compounds. AQPs are present in many organisms, including bacteria and humans. Thirteen AQP family members have been identified in humans (AQP0-12) and are expressed in various organs. ${ }^{34)}$

In the skin, AQP3 is predominantly expressed in the stratum basal and stratum spinosum. Because the water content of the stratum corneum is reduced in AQP3 knockout mice, AQP3 is thought to play an important role in maintaining normal water levels in the skin. ${ }^{35,36)}$ Following acute barrier disruption by tape stripping, AQP3-deficient mice also exhibit delayed barrier recovery. ${ }^{37)} \mathrm{AQP} 3$ is also important in wound healing, facilitating keratinocyte migration and enhancing keratinocyte proliferation and differentiation. ${ }^{38)}$ In our previous study, we demonstrated that Gypsum fibrosum increased the expression level of cutaneous AQP3 in mice. ${ }^{6}$ In this study, the mechanism of the Gypsum fibrosum-induced increase in cutaneous AQP3 expression was investigated using a human keratinocyte cell line.

First, whether Gypsum fibrosum was capable of increasing the expression level of AQP3 in the keratinocyte cell line was investigated. It was revealed that Gypsum fibrosum significantly increased the expression of AQP3, both at the mRNA and the protein levels (Fig. 1). Similar increases in AQP3 mRNA and protein were also observed after the addition of $\mathrm{CaSO}_{4}$, a main component of Gypsum fibrosum (Fig. 1). The increase in the expression of AQP3 due to treatment with Gypsum fibrosum or $\mathrm{CaSO}_{4}$ was dose-dependent (Fig. 1A).

The exact mechanism by which the addition of Gypsum fibrosum or $\mathrm{CaSO}_{4}$ caused the increase in the expression level of AQP3 in keratinocytes was unclear. In our previous study, we showed that Gypsum fibrosum increased the concentration of cutaneous $\mathrm{Ca}^{6}$ ) In addition, it was reported that $\mathrm{CaCl}_{2}$ increased the expression level of AQP3 in keratinocytes. ${ }^{39)}$ The intracellular $\mathrm{Ca}$ concentration was measured in keratinocytes $1 \mathrm{~h}$ after the addition of Gypsum fibrosum or $\mathrm{CaSO}_{4}$. The intracellular Ca concentration increased significantly to approximately 2.5-fold the level observed in the control cells (Fig. 2). These results were almost identical with the results of a previous in vivo study, which indicated that the expression level of cutaneous AQP3 increased when the Ca concentration in the skin increased approximately two-fold in mice. Furthermore, it is known that the expression levels of AQPs increase in response to hyperosmotic stimulation. ${ }^{40,41)}$ However, the concentration of Gypsum fibrosum or $\mathrm{CaSO}_{4}$ used in this study (approximately $1 \mathrm{~mm}, 2 \mathrm{mOsm}$ ) did not exert any effect on the osmotic pressure of the medium (approximately $300 \mathrm{mOsm}$ ).

An increase in the intracellular $\mathrm{Ca}$ concentration activates PKC. ${ }^{21)}$ When PKC is activated, cytoplasmic ERK is phosphorylated $^{25-27)}$ and translocates to the nucleus, where it regulates the phosphorylation of CREB. ${ }^{28-30)}$ Phosphorylated 
CREB accelerates the transcription of AQPs, leading to an increase in the protein expression level of AQPs. ${ }^{12,42)}$ The determination of the PKC activity in keratinocytes $1 \mathrm{~h}$ after the addition of Gypsum fibrosum revealed an approximately 3-fold significant increase in the activity of PKC compared with that observed in control cells (Fig. 3). An increase in the levels of phosphorylated of ERK and CREB was also observed following the addition of Gypsum fibrosum (Fig. 4). The changes caused by Gypsum fibrosum were similar to those observed for $\mathrm{CaSO}_{4}$ (Figs. 2-4). Based on these results, it was suggested that the increase in the concentration of intracellular Ca triggered the increase in the expression level of AQP3 in keratinocytes. In addition, it was suggested that Gypsum fibrosum might cause the increase in the AQP3 expression level of keratinocytes by activating the PKC-ERK-CREB pathway.

To examine the involvement of this pathway in AQP3 expression, the effect of a PKC inhibitor, GF109203X, ${ }^{31,32)}$ on AQP3 expression was studied. Pre-treatment with GF109203X almost completely suppressed the increase in AQP3 expression caused by Gypsum fibrosum or $\mathrm{CaSO}_{4}$ (Fig. 5). Based on this result, it was suggested that Gypsum fibrosum might cause the increase in PKC activity in keratinocytes, which leads to the increased transcription of AQP3.

Although it remains unclear why the intracellular Ca concentration increased after the addition of Gypsum fibrosum or $\mathrm{CaSO}_{4}$ in this study, we propose the following mechanism. Keratinocytes express the calcium sensing receptor (CaR), a G-protein-coupled receptor. ${ }^{43,44)}$ Activation of $\mathrm{CaR}$ with $\mathrm{Ca}$ activates phospholipase C (PLC), which converts phosphatidylinositol 4,5-bisphosphonate into diacylglycerol and inositol triphosphate $\left(\mathrm{IP}_{3}\right)$. $\mathrm{IP}_{3}$ binds to its receptor, $\mathrm{IP}_{3} \mathrm{R}$, in the endoplasmic reticulum and Golgi apparatus membrane and triggers the release of $\mathrm{Ca}$ from internal stores, resulting in an acute increase in intracellular $\mathrm{Ca} .{ }^{45)}$

Byakkokaninjinto and Byakkoto, which both contain a large amount of Gypsum fibrosum, are used to relieve symptoms of fever and excessive water drinking because when water is not utilized in the body but is instead excreted in the urine, the feces is dry, hard, and round. Byakkokaninjinto and Byakkoto are administered to humans whose absorbed water is not used in the body but is excreted. Gypsum fibrosum increased the expression level of cutaneous AQP3, which demonstrates that the Gypsum fibrosum in Byakkokaninjinto and Byakkoto moistens the dry body by attracting water from intravascular to extravascular due to the increased expression of cutaneous AQP3. This mechanism of action of Gypsum fibrosum, which we newly discovered, rationally explains the targets of Byakkokaninjinto and Byakkoto. In contrast, Anemarrhena rhizome, which is a component herbal medicine of Byakkokaninjinto and Byakkoto, improves "water retention." Anemarrhena rhizome contains timosaponin A II, which has an intracellular $\mathrm{Ca}$ concentration-increasing effect ${ }^{46)}$; however, it remains unknown why Anemarrhena rhizome and Gypsum fibrosum are used simultaneously. We propose that the mechanism that causes the increase in AQP3 expression by Gypsum fibrosum is induced by the increase in the $\mathrm{Ca}$ concentration to explain the significance of the combined formulation of Anemarrhena rhizome and Gypsum fibrosum in Byakkokaninjinto and Byakkoto. We thus consider that the results of this study are also interesting because they present a scientific basis for the efficacy of Byakkokaninjinto and Byakkoto.
It is known that Gypsum fibrosum improves the symptoms of cutaneous pruritus; however, the mechanism of action by which Gypsum fibrosum alleviates these symptoms was unclear. The results of this study revealed that Gypsum fibrosum increased cutaneous AQP3, resulting in the prevention of dry skin, which eventually leads to the improvement of cutaneous pruritus. First, Gypsum fibrosum increases the intracellular concentration of $\mathrm{Ca}$ in the skin. This increase in $\mathrm{Ca}$ leads to PKC activation and enhanced phosphorylation of ERK and CREB. As a result, transcription of AQP3 mRNA is promoted, leading to an increase in protein expression of AQP3. AQP3 is a member of the AQP family that is predominantly expressed in the skin and plays a role in the regulation of cutaneous water content, as well as in wound healing. The findings of this study suggest the possibility that Gypsum fibrosum or $\mathrm{Ca}$ may be useful for the treatment of skin diseases and burns, as well as for the regeneration of skin.

\section{REFERENCES}

1) Yuan D, Sunouchi H, Sakurai T, Saito K, Kano Y. Pharmacological properties of traditional medicines (XXVII). Interaction between Ephedra herb and Gypsum under hyperthermal conditions in rats. Biol. Pharm. Bull., 25, 872-874 (2002).

2) Kimura M, Kimura I, Chem FJ. Combined potentiating effect of byakko-ka-ninjin-to, its constituents, rhizomes of Anemarrhena asphodeloides, tomosaponin A-III, and calcium on pilocarpineinduced saliva secretion in streptozocin-diabetic mice. Biol. Pharm. Bull., 19, 926-931 (1996).

3) Ikarashi $\mathrm{N}$, Toda $\mathrm{T}$, Okaniwa $\mathrm{T}$, Ito $\mathrm{K}$, Ochiai $\mathrm{W}$, Sugiyama K. Anti-obesity and anti-diabetic effects of acacia polyphenol in obese diabetic KKAy mice fed high-fat diet. Evid. Based Complement. Alternat. Med., 2011, 952031 (2011).

4) Satake M, Ikarashi N, Ichikawa Y, Maniwa A, Toda T, Ito K, Ochiai W, Sugiyama K. The role of renal aquaporin 2 in the alleviation of dehydration associated with diabetic polyuria in KKAy mice. Life Sci., 87, 475-480 (2010).

5) Aburada T, Ikarashi N, Kagami M, Ichikawa Y, Sugitani M, Maniwa A, Ueda $\mathrm{H}$, Toda $\mathrm{T}$, Ito $\mathrm{K}$, Ochiai W, Matsushita R, Miyamoto K, Sugiyama K. Byakkokaninjinto prevents body water loss by increasing the expression of kidney aquaporin-2 and skin aquaporin-3 in KKAy mice. Phytother. Res., 25, 897-903 (2011).

6) Ikarashi N, Ogiue N, Toyoda E, Kon R, Ishii M, Toda T, Aburada T, Ochiai W, Sugiyama K. Gypsum fibrosum and its major component $\mathrm{CaSO} 4$ increase cutaneous aquaporin-3 expression levels. J. Ethnopharmacol., 139, 409-413 (2012).

7) Ishibashi Y, Sugita T, Nishikawa A. Cytokine secretion profile of human keratinocytes exposed to Malassezia yeasts. FEMS Immunol. Med. Microbiol., 48, 400-409 (2006).

8) Taniguchi A, Matsumoto K. Down-regulation of human sialyltransferase gene expression during in vitro human keratinocyte cell line differentiation. Biochem. Biophys. Res. Commun., 243, 177-183 (1998).

9) Abiko Y, Nishimura M, Kusano K, Yamazaki M, Arakawa T, Takuma T, Kaku T. Upregulated expression of human beta defensin-1 and -3 mRNA during differentiation of keratinocyte immortalized cell lines, HaCaT and PHK16-0b. J. Dermatol. Sci., 31, 225-228 (2003).

10) Taniguchi A, Matsumoto K. Down-regulation of human sialyltransferase gene expression during in vitro human keratinocyte cell line differentiation. Biochem. Biophys. Res. Commun., 243, 177-183 (1998).

11) Ikarashi N, Baba K, Ushiki T, Kon R, Mimura A, Toda T, Ishii M, Ochiai W, Sugiyama K. The laxative effect of bisacodyl is attribut- 
able to decreased aquaporin- 3 expression in the colon induced by increased PGE2 secretion from macrophages. Am. J. Physiol. Gastrointest. Liver Physiol., 301, G887-G895 (2011).

12) Ikarashi N, Mochiduki T, Takasaki A, Ushiki T, Baba K, Ishii M, Kudo T, Ito K, Toda T, Ochiai W, Sugiyama K. A mechanism by which the osmotic laxative magnesium sulphate increases the intestinal aquaporin 3 expression in HT-29 cells. Life Sci., 88, 194-200 (2011).

13) Silberstein C, Kierbel A, Amodeo G, Zotta E, Bigi F, Berkowski D, Ibarra C. Functional characterization and localization of AQP3 in the human colon. Braz. J. Med. Biol. Res., 32, 1303-1313 (1999).

14) Spector DA, Wade JB, Dillow R, Steplock DA, Weinman EJ. Expression, localization, and regulation of aquaporin-1 to -3 in rat urothelia. Am. J. Physiol. Renal Physiol., 282, F1034-F1042 (2002).

15) Baumgarten R, Van De Pol MH, Wetzels JF, Van Os CH, Deen PM. Glycosylation is not essential for vasopressin-dependent routing of aquaporin-2 in transfected Madin-Darby canine kidney cells. $J$. Am. Soc. Nephrol., 9, 1553-1559 (1998).

16) Hendriks G, Koudijs M, van Balkom BW, Oorschot V, Klumperman J, Deen PM, van der Sluijs P. Glycosylation is important for cell surface expression of the water channel aquaporin-2 but is not essential for tetramerization in the endoplasmic reticulum. J. Biol. Chem., 279, 2975-2983 (2004).

17) Umenishi F, Narikiyo T, Schrier RW. Effect on stability, degradation, expression, and targeting of aquaporin-2 water channel by hyperosmolality in renal epithelial cells. Biochem. Biophys. Res. Commun., 338, 1593-1599 (2005).

18) Ikarashi N, Mimura A, Kon R, Iizasa T, Omodaka M, Nagoya C, Ishii M, Toda T, Ochiai W, Sugiyama K. The concomitant use of an osmotic laxative, magnesium sulphate, and a stimulant laxative, bisacodyl, does not enhance the laxative effect. Eur. J. Pharm. Sci., 45, 73-78 (2012).

19) Ikarashi N, Sato W, Toda T, Ishii M, Ochiai W, Sugiyama K. Inhibitory effect of polyphenol-rich fraction from the bark of Acacia mearnsii on itching associated with allergic dermatitis. Evid. Based Complement. Alternat. Med., 2012, 120389 (2012).

20) Ikarashi N, Ushiki T, Mochizuki T, Toda T, Kudo T, Baba K, Ishii M, Ito K, Ochiai W, Sugiyama K. Effects of magnesium sulphate administration on aquaporin 3 in rat gastrointestinal tract. Biol. Pharm. Bull., 34, 238-242 (2011).

21) Deucher A, Efimova T, Eckert RL. Calcium-dependent involucrin expression is inversely regulated by protein kinase C (PKC)alpha and PKCdelta. J. Biol. Chem., 277, 17032-17040 (2002).

22) Asai M, Higuchi S, Kubota M, Iguchi K, Usui S, Hirano K. Regulators for blood glucose level affect gene expression of aquaporin 3. Biol. Pharm. Bull., 29, 991-996 (2006).

23) Okuno K, Taya K, Marmarou CR, Ozisik P, Fazzina G, Kleindienst A, Gulsen S, Marmarou A. The modulation of aquaporin-4 by using PKC-activator (phorbol myristate acetate) and Vla receptor antagonist (SR49059) following middle cerebral artery occlusion/reperfusion in the rat. Acta Neurochir. Suppl. (Wien), 102, 431-436 (2008).

24) Tie L, Lu N, Pan XY, Pan Y, An Y, Gao JW, Lin YH, Yu HM, Li XJ. Hypoxia-induced up-regulation of aquaporin-1 protein in prostate cancer cells in a p38-dependent manner. Cell. Physiol. Biochem., 29, 269-280 (2012).

25) Li Z, Wang N, Fang J, Huang J, Tian F, Li C, Xie F. Role of PKCERK signaling in tamoxifen-induced apoptosis and tamoxifen resistance in human breast cancer cells. Oncol. Rep., 27, 1879-1886 (2012).

26) Soetikno V, Sari FR, Sukumaran V, Lakshmanan AP, Mito S, Harima M, Thandavarayan RA, Suzuki K, Nagata M, Takagi $\mathrm{R}$, Watanabe K. Curcumin prevents diabetic cardiomyopathy in streptozotocin-induced diabetic rats: Possible involvement of PKCMAPK signaling pathway. Eur. J. Pharm. Sci., 47, 604-614 (2012).

27) Tang JM, Yuan J, Li Q, Wang JN, Kong X, Zheng F, Zhang L,
Chen L, Guo LY, Huang YH, Yang JY, Chen SY. Acetylcholine induces mesenchymal stem cell migration via $\mathrm{Ca}(2+) / \mathrm{PKC} / \mathrm{ERK} 1 / 2$ signal pathway. J. Cell. Biochem., 113, 2704-2713 (2012).

28) Adachi M, Fukuda M, Nishida E. Two co-existing mechanisms for nuclear import of MAP kinase: passive diffusion of a monomer and active transport of a dimer. EMBO J., 18, 5347-5358 (1999).

29) Khokhlatchev AV, Canagarajah B, Wilsbacher J, Robinson M, Atkinson M, Goldsmith E, Cobb MH. Phosphorylation of the MAP kinase ERK2 promotes its homodimerization and nuclear translocation. Cell, 93, 605-615 (1998).

30) Yao H, Peng F, Fan Y, Zhu X, Hu G, Buch SJ. TRPC channel-mediated neuroprotection by PDGF involves Pyk2/ERK/CREB pathway. Cell Death Differ., 16, 1681-1693 (2009).

31) Lui KE, Panchal AS, Santhanagopal A, Dixon SJ, Bernier SM. Epidermal growth factor stimulates proton efflux from chondrocytic cells. J. Cell. Physiol., 192, 102-112 (2002).

32) Sobolewski A, Jourdan KB, Upton PD, Long L, Morrell NW. Mechanism of cicaprost-induced desensitization in rat pulmonary artery smooth muscle cells involves a PKA-mediated inhibition of adenylyl cyclase. Am. J. Physiol. Lung Cell. Mol. Physiol., 287, L352-L359 (2004).

33) Ishibashi K, Hara S, Kondo S. Aquaporin water channels in mammals. Clin. Exp. Nephrol., 13, 107-117 (2009).

34) Fujiyoshi Y, Mitsuoka K, de Groot BL, Philippsen A, Grubmuller $\mathrm{H}$, Agre P, Engel A. Structure and function of water channels. Curr. Opin. Struct. Biol., 12, 509-515 (2002).

35) Hara-Chikuma M, Verkman AS. Aquaporin-3 functions as a glycerol transporter in mammalian skin. Biol. Cell, 97, 479-486 (2005).

36) Ma T, Hara M, Sougrat R, Verbavatz JM, Verkman AS. Impaired stratum corneum hydration in mice lacking epidermal water channel aquaporin-3. J. Biol. Chem., 277, 17147-17153 (2002).

37) Hara M, Ma T, Verkman AS. Selectively reduced glycerol in skin of aquaporin-3-deficient mice may account for impaired skin hydration, elasticity, and barrier recovery. J. Biol. Chem., 277, 4661646621 (2002).

38) Hara-Chikuma M, Verkman AS. Aquaporin-3 facilitates epidermal cell migration and proliferation during wound healing. J. Mol. Med. (Berl.), 86, 221-231 (2008).

39) Jiang YJ, Kim P, Lv YF, Feingold KR. PPARgamma activators stimulate aquaporin-3 expression in keratinocyte/epidermis. Exp. Dermatol., 20, 595-599 (2011).

40) Matsuzaki T, Suzuki T, Takata K. Hypertonicity-induced expression of aquaporin 3 in MDCK cells. Am. J. Physiol. Cell Physiol., 281, C55-C63 (2001).

41) Sugiyama Y, Ota Y, Hara M, Inoue S. Osmotic stress up-regulates aquaporin-3 gene expression in cultured human keratinocytes. Biochim. Biophys. Acta, 1522, 82-88 (2001).

42) Okahira M, Kubota M, Iguchi K, Usui S, Hirano K. Regulation of aquaporin 3 expression by magnesium ion. Eur. J. Pharmacol., 588, 26-32 (2008)

43) Oda Y, Tu CL, Chang W, Crumrine D, Komuves L, Mauro T, Elias PM, Bikle DD. The calcium sensing receptor and its alternatively spliced form in murine epidermal differentiation. J. Biol. Chem., 275, 1183-1190 (2000).

44) Tu CL, Chang W, Bikle DD. The extracellular calcium-sensing receptor is required for calcium-induced differentiation in human keratinocytes. J. Biol. Chem., 276, 41079-41085 (2001)

45) Berridge MJ. Inositol trisphosphate and calcium signalling. Nature, 361, 315-325 (1993).

46) Wang GJ, Lin LC, Chen CF, Cheng JS, Lo YK, Chou KJ, Lee KC, Liu CP, Wu YY, Su W, Chen WC, Jan CR. Effect of timosaponin A-III, from Anemarrhenae asphodeloides BUNGE (Liliaceae), on calcium mobilization in vascular endothelial and smooth muscle cells and on vascular tension. Life Sci., 71, 1081-1090 (2002). 